\title{
PENYULUHAN PEMANFAATAN PAKAN TERNAK ALTERNATIF DI DESA PENGKELAK MAS KABUPATEN LOMBOK TIMUR
}

\section{Counseling The Utilization of Husbandry Food Alternative In Pengkelak Mas Village, East Lombok District}

\section{Dwi Kusuma Purnamasari*, Syamsuhaidi, Erwan, Sumiati, Pardi, Uhud Abdullah, Sri Sulastri}

Program Studi Peternakan Universitas Mataram

Jl. Majapahit No. 62, Kota Mataram

*Alamat Korespondensi: emmadkp03@gmail.com

(Tanggal Submission: 2 April 2021, Tanggal Accepted : 9 April 2021)

\section{Keyword: Abstrak :}

alternatif Desa Pengkelak Mas merupakan salah satu desa di Kecamatan Sakra Barat Kabupaten pakan ternak, lamtoro, desa pengkelak mas Lombok Timur yang merupakan daerah yang kering dengan ketersediaan pakan hijauan yang rendah terutama pada musim kemarau. Pada saat tersebut masyarakat desa masih memelihara ternak secara tradisional, yaitu ternak dilepas di padang penggembalaan pada pagi hingga sore hari tanpa memperhatikan kecukupan pakan yang tersedia di padang penggembalaan. Kegiatan pengabdian kepada masyarakat bertujuan untuk menyampaikan informasi dan pengetahuan mengenai pemanfaatan pakan ternak alternative yang dapat digunakan oleh masyarakat. Kegiatan pengabdian dilakukan dengan metode penyuluhan yang dilanjutkan dengan penanaman bibit tanaman pakan alternatif berupa lamtoro. Kegiatan pengabdian diikuti sekitar 35 orang yang terdiri dari masyarakat tani ternak, pengurus desa, dan tokoh masyarakat desa Pengkelak Mas. Peserta pengabdian antusias mengikuti kegiatan penyuluhan mengenai manajemen memelihara ternak pada daerah kering dengan memanfaatkan bahan pakan alternatif seperti limbah jagung dan limbah nanas. Kegiatan selajutnya adalah diskusi, yaitu membahas permasalahanpermasalahan yang dialami peternak dan menyampaikan solusi-solusi yang dapat dilakukan oleh peternak. Berdasarkan permasalahan-permasalahan yang terungkap, maka diberikan berbagai alternatif-alternatif solusi yang dapat dilakukan. Kesimpulan dari kegiatan pengabdian, masyarakat mendapatkan tambahan informasi dan semangat dalam meningkatkan produktifitas ternak dengan memanfaatkan bahanbahan pakan alternatif yang ada di Desa Pengkelak Mas.

Panduan sitasi / Citation guidance (APPA $7^{\text {th }}$ edition) :

Purnamasari, D. K., Syamsuhaidi, Erwan, Sumiati, Pardi, Abdullah, U., \& Sulastri, S. (2021). Penyuluhan Pemanfaatan Pakan Ternak Alternatif Di Desa Pengkelak Mas Kabupaten Lombok Timur. Jurnal Abdi Insani Universitas Mataram, 8 (1), 32-38. http://doi.org/10.29303/abdiinsani.v8i1.372. 


\section{PENDAHULUAN}

Penyuluhan peternakan merupakan salah satu kegiatan penyampaian informasi/pengetahuan atau pembinaan dimana target/sasarannya yaitu para petani/peternak. Diharapkan dari kegiatan penyuluhan peternakan akan terjadi perubahan perilaku, dari mulai aspek yang bersifat kognitif, afektif dan akhirnya psikomotorik. Proses perubahan perilaku melalui pendidikan salah satunya adalah penyuluhan akan memakan waktu lebih lama, tetapi perubahan perilaku yang terjadi akan berlangsung lebih kekal. Oleh karena itu penyuluhan merupakan investasi pembinaan petani/peterbak untuk masa depan. Penyuluhan dapat bersifat aktif dan pasif, aktif merupakan kegiatan penyuluhan yang rutin diprogramkan oleh instansi terkait maupun dari akademisi dalam rangka penyampaian informasi/pengetahuan dan pembinaan kepada petani/peternak. Kegiatan penyuluhan pasif merupakan kegiatan yang diadakan oleh instansi terkait dan akademisi berdasarkan permintaan dari masyarakat atau petani/peternak sesuai dengan kebutuhannya.

Penyuluhan Pakan Ternak Alternatif di Desa Pengkelak Mas Kecamatan Sakra Barat Kabupaten Lombok Timur merupakan penyuluhan pasif berdasarkan pada permintaan dari mahasiswa KKN yang melihat potensi Desa Pengkelak Mas dalam bidang peternakan, namun selama ini belum pernah ada pembinaan baik dari instansi pemerinta daerah maupun dari akademisi. Pengkelak Mas merupakan salah satu desa yang ada di Kecamatan Sakra Barat, Kabupaten Lombok Timur, Provinsi Nusa Tenggara Barat, Indonesia. Desa Pengkelak Mas merupakan satu dari 19 desa yang berada di Kecamatan Sakra Barat. Desa ini memiliki jumlah penduduknya sebagian besar bersuku daerah sasak, terletak di bagian timur pulau Lombok. Desa Pengkelak Mas terbagi menjadi 3 (tiga) kepala wilayah (dusun) yakni Dusun Pengkelak Mas, Dusun Tanjah-Anjah dan Dusun Penandak (Wikipedia, 2019).

Sakra Barat merupakan pemekaran dari Kecamatan Sakra, dengan penetapan ibu kota di Rensing. Desa ini dijadikan sebagai ibu kota Kecamatan Sakra Barat dengan alasan secara historis karena desa ini mengalami pertumbuhan paling dinamis jika dibandingkan dengan desa lainnya. Di salah satu dusun yang terletak di Desa Rensing, yakni Peteluan, terdapat sebuah terminal strategis dengan jalur yang ramai dan didukung infrastruktur yang cukup baik, sehingga mendukung pertumbuhan ekonomi yang cukup baik pula. Kecamatan Sakra Barat memiliki luas wilayah $33,7 \mathrm{Km}^{2}$ dan umumnya merupakan daerah dengan kontur berbukit pada ketinggian 0-250 meter dari permukaan laut. Jumlah Penduduk Kecamatan Sakra Barat dari tahun ke tahun terus mengalami peningkatan. Jumlah penduduk pada pertengahan tahun 2007 tercatat sebanyak 45,070 jiwa dengan rincian laki-laki sebanyak 18.862 jiwa dan perempuan sebanyak 26.208 jiwa. Dibandingkan dengan luas wilayah, maka kepadatan penduduk di kecamatan Sakra Barat tercatat sebesar 1.337 jiwa per $\mathrm{Km}^{2}$. Di antara semua desa yang ada di kecamatan Sakra Barat, desa Rensing memiliki kepadatan penduduk yang paling tinggi yaitu 1.924 jiwa per $\mathrm{Km}^{2}$ sedangkan desa Sukarara memiliki kepadatan terendah dengan $911 \mathrm{jiwa} \mathrm{Km}^{2}$. Daerah Sakra merupakan wilayah dengan areal pertanian yang cukup luas. Komoditi pertanian utamanya adalah tembakau jenis Virginia, padi, serta kacang-kacangan. Saat ini, kecamatan Sakra Barat sudah bisa mendapatkan air irigasi dari bendungan Pandan Duri hingga beberapa daerah memiliki 3 musim tanam pertahun, dimana yang semula hanya 2 musim tanam saja. Dua musim tanam pertama dilakukan pada musim penghujan untuk menanam padi, sedangkan satu musim tanamnya pada musim kemarau untuk menanam tembakau (Wikipedia, 2019).

Mata pencaharian masyarakat desa Pengkelak Mas umumnya adalah bertani dan beternak, dengan kepemilikan ternak sapi per orang yang tidak banyak, yaitu 3-5 ekor dan ternak unggas umumnya ayam kampung yang sedikit sekitar 10 ekor per orang. Usaha peternakan masih dikelola sendiri dan belum terbentuk kelompok ternak serta masih merupakan usaha sampingan. 
Permasalahan yang dihadapi peternak adalah masalah pakan yang sangat sulit didapat di daerah sekitar dikarenakan merupakan daerah kering, sehingga peternak harus mencari sumber pakan yang jauh dari tempat tinggal. Berdasarkan hal tersebut, mahasiswa KKN merasa perlu dilakukan penyuluhan mengenai pemanfaatan pakan alternatif di desa Pengkelak Mas.

Pakan alternatif adalah pakan buatan sendiri dari bahan-bahan lokal yang dicampur sendiri untuk mendapatkan pakan dengan nutrisi yang cukup untuk pertumbuhan, pakan ini mungkin tidak sebaik pakan buatan pabrik tetapi yang jelas sangat lebih murah dan mudah diperoleh dan akan memberikan hasil yang memuaskan dibanding dengan pakan buatan pabrik, hal ini karena pakan telah di rekayasa sehingga memenuhi kebutuhan nutrisi untuk ternak baik kandungan protein, energi metabolisme, kandungan lemak, batasan kandungan serat kasar serta vitamin dan mineral yang diperlukan dengan menggunakan bahan bahan hasil pertanian yang mudah di dapat disekeliling. Beberapa pakan alternatif yang berasal dari limbah pengolahan makanan seperti onggok, molasses, ampas tahu, ampas kecap, CPO, dll sudah banyak digunakan sebagai pakan ternak. Penggunaannya sebagai bahan pakan dapat dicampurkan dengan bahan tambahan pakan lainnya atau bisa juga diberikan secara langsung pada ternak.

Berbagai penelitian dengan tujuan untuk meminimalisasi biaya pakan terus dilakukan, salah satunya dengan memanfaatkan bahan-bahan pakan yang tersedia di daerah sekitar dan ketersediaannya berlimpah. Penelitian difokuskan mencari bahan-bahan pakan sumber protein baik yang berasal dari nabati maupun hewani. Penelitian penggunaan berbagai bahan pakan alternatif sumber protein hewani dalam rangka mengurangi penggunaan pakan komplit atau mengganti penggunaan tepung ikan telah dilakukan dan memberikan hasil yang signifikan. Purnamasari dkk. (2015) melakukan penelitian penggunaan tepung ikan rajungan pada itik petelur memberikan hasil yang signifikan $(P<0,01)$ terhadap tebal kerabang telur dan warna kuning telur $(P<0,05)$. Hasil penelitian Shahidi, dkk. (1999), bahwa pemberian kitin dari cangkang rajungan mencapai $2 \%$ mampu meningkatkan konsentrasi HDL pada ayam pedaging, namun ternyata belum dapat menurunkan kolesterol serum dan triasilgliserol pada ayam pedaging, kelinci, dan ayam petelur.

Purnamasari dkk (2011) juga melakukan penelitian tentang potensi ikan sapu sapu sebagai pakan unggas. Dihasilkan bahwa ikan sapu-sapu memiliki kandungan nutrisi yang lengkap dengan kadar protein kasar tinggi berkisar 33.32 - 41.75\%, kadar abu berkisar $29.58-38.81 \%$, kadar lemak kasar berkisar $13.29-22.97 \%$, kadar serat kasar $0.80-3.39 \%$ serta energi $5290.40-5881.68 \mathrm{Kkal} / \mathrm{Kg}$. Selain itu kandungan mineral khususnya Ca dan P ikan sapu sapu cukup tinggi (3.59-4.26\% dan 0.29 - $0.99 \%$ ) yang berasal dari struktur pertulangan dan kepala ikan sapu sapu yang keras. Kandungan nutrisi ikan sapu sapu berperan dalam pembentukkan kerabang telur dan produksi telur yang tetap stabil. Penggunaan limbah udang yang difermentasi dengan A. Niger pada pakan broiler juga telah diteliti oleh Irfan, et al., (2009), yang menghasilkan bahwa pemberian lebih dari 7,5\% menurunkan bobot hidup 3 minggu bobot hidup akhir dan konsumsi pakan. Sutama (2014) mengkaji pemberian 10, 20, dan 30\% kapu kapu (Pistoia stratiotes) pada ayam kampung, ternyata mampu menurunkan kadar LDL serum dan kolesterol total pada daging dan disisi lain mampu meningkatkan HDL serum secara nyata. Biyatmoko dan Nurliani (2012), menambahkan niacin dalam pakan berserat yang disuplementasi minyak ikan dan jagung pada pakan itik alabio, ternyata pemberian niacin sebesar 1500 ppm nyata menurunkan kadar kolesterol telur itik pada kisaran 49,6 mg/g.

Selain bahan pakan sumber hewani yang merupakan limbah dapat dimanfaatkan sebagai pakan alternatif, limbah pertanian juga dapat dijadikan sebagai pakan alternatif baik untuk ternak ruminansia maupun non ruminansia. Pengabdian ini bertujuan untuk meningkatkan pengetahuan dan wawasan masyarakat tani ternak dan masyarakat lainnya, meningkatnya semangat masyarakat tani ternak dan masyarakat lainnya dalam mengembangkan usaha peternakan secara 
mandiri berbasis bahan pakan lokal dan alternatif, dan meningkatnya jumlah tanaman lamtoro di desa Pengkelak Mas.

\section{METODE}

Kegiatan pengabdian masyarakat ini dilaksanakan dalam bentuk antara lain:

1. Diskusi bersama-sama masyarakat tani ternak, pengurus desa, tokoh-tokoh masyarakat dan masyarakat lainnya untuk memecahkan permasalahan yang timbul dan memecahkan permasalahan tersebut dengan solusi yang tepat secara bersama-sama serta menggali potensi-potensi yang ada untuk dikembangkan

2. Memberikan pengetahuan dan gambaran untuk mengembangkan usaha beternak unggas dengan metode penyuluhan dan diskusi interactive'.

3. Merumuskan jenis-jenis pakan lokal dan alternatif yang dapat digunakan sebagai pakan baik ternak besar maupun kecil.

4. Menggalakkan penanaman bibit lamtoro dengan pemberian bibit lamtoro kepada Pengurus Desa Pengkelak Mas

5. Melakukan evaluasi dan apabila dari kegiatan evaluasi masyarakat yang ikut banyak dan antusias serta semangat dalam mengikuti program pengabdian, maka akan dilakukan pendampingan selanjutnya.

6. Merumuskan bersama program lanjutan yang harus segera dilaksanakan dan dibutuhkan masyarakat desa untuk dimasukkan dalam program kerja desa, sehingga masyarakat lebih terarah dan usaha peternakan memberikan hasil yang maksimal

\section{HASIL DAN PEMBAHASAN}

Kegiatan pengabdian diawali diskusi bersama dengan melibatkan mahasiswa, alumni, pengurus dan masyarakat tani ternak Desa Pengkelak Mas. Berdasarkan hasil diskusi diketahui berbagai potensi dan permasalahan yang dialami peternak. Potensi Desa Pengkelak Mas adalah peternakan sapi, dimana rata-rata masyarakat memiliki dan atau mengadas sapi berkisar 2-3 ekor. Namun permasalahan yang dialami adalah ketersediaan pakan, yang mana pada musim hujan pakan tersedia cukup dan ketika musim kering peternak mengalami kesulitan dalam menyediakan pakan. Desa Pengkelak |Mas merupakan salah satu desa yang tingkat kekeringan tanahnya tinggi dan biasanya berlangsung cukup lama. Di saat musim kemarau, peternak harus mencari pakan di luar desa bahkan terjauh hingga ke daerah Kabupaten Lombok Tengah di sekitar Bendungan Batujai. Namun terkadang kemampuan peternak dalam mencari pakan terbatas, sehingga peternak membiarkan ternaknya mencari pakan sendiri di lahan-lahan pertanian yang ketersediaan hijauan makanan ternak sudah sangat terbatas, sehingga nampak sapi-sapi yang berada di Desa Pengkelak Mas ini kondisinya tubuhnya kurus.

Untuk mengatasi permasalahan peternak, maka diberikan materi penyuluhan berupa:

1. Strategi penyediaan pakan hijauan pada musim kemarau dengan melakukan pengolahan atau pengawetan pakan hijauan yang tersedia berlimpah pada musim hujan dengan metode fermentasi hijauan menjadi silase. Silase kemudian dapat disimpan dalam waktu setahun untuk diberikan pada sapi saat musim kemarau.

2. Bahan-bahan pakan alternatif yang berupa limbah-limbah pertanian dan perkebunan yang dapat dijadikan sebagai pakan ternak. Desa Pengkelak Mas menghasilkan banyak limbah tanaman jagung, kedelai, dan kacang-kacangan lainnya. 
3. Pemanfaatan tanaman leguminosa seperti turi, kelor, lamtoro, gamal yang tersedia di sekitar desa Pengkelak Mas sebagai pakan sapi.

4. Penggalakkan penanaman lamtoro di sekitar pekarangan rumah, pematang-pematang sawah, dan di tanah-tanah kosong di desa Pengkelak Mas.

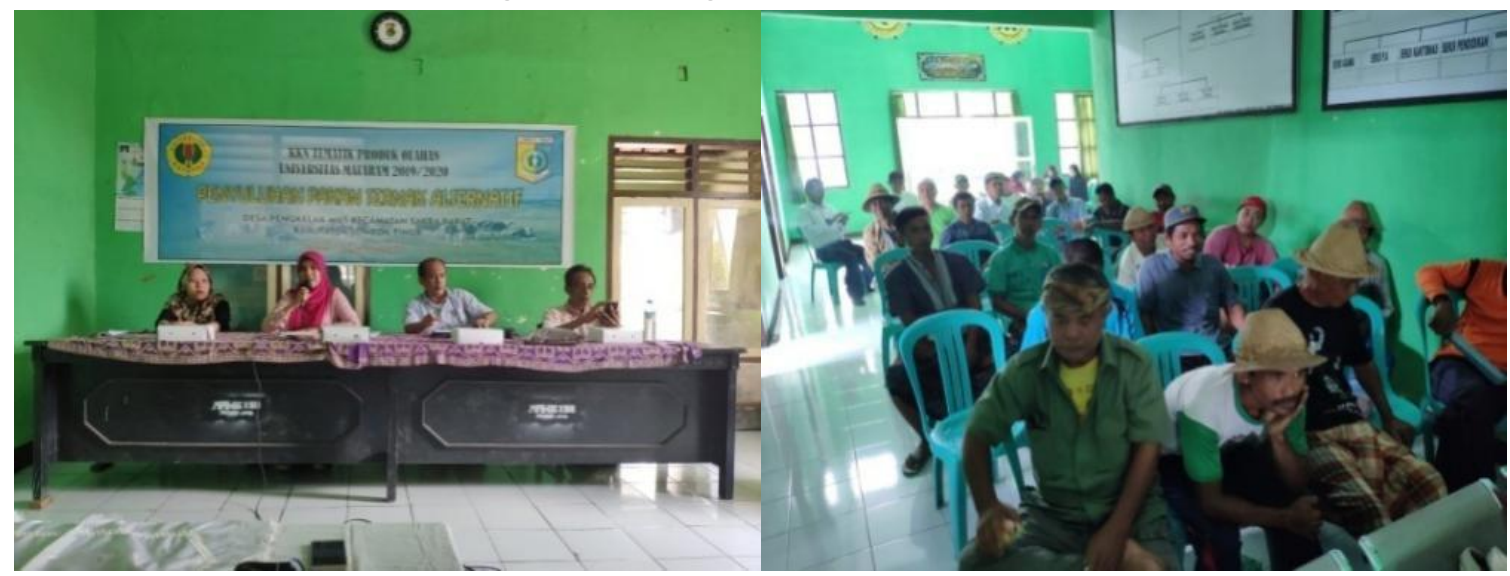

Gambar 1. Suasana Penyampaian Materi dan Diskusi

Penggalakan penanaman lamtoro merupakan solusi untuk penyediaan pakan berkualitas pada daerah kering. Salah satu varietas lamtoro yang sudah berkembang baik di Indonesia adalah varietas teramba. Berdasarkan penelitian Yurmiaty dan Suradi (2010) lamtoro varietas teramba (Leucaena leucocephalacv. tarramba) memiliki keunggulan tahan pada musim kering dan terhadap hama kutu loncat. Tanaman lamtoro mampu beradaptasi dengan baik di daerah tropis. Selain itu, lamtoro mampu beradaptasi pada tanah dengan kemasaman sedang antara pH 5.5 - 6.5 dan beriklim sedang dengan curah hujan tahunan di atas $760 \mathrm{~mm}$ (Hoult dan Briant 1974 dalam Manpaki, S.J., dkk., 2017).

Konsorsium Riset Ruminansia Besar (KRRB) Universitas Mataram telah mengomandani proyek Koridor Ekonomi Bali-NTB 2018 melalui program penggemukan sapi berbasis pakan daun lamtoro atau dikenal Sapi Lamtoro (Times Indonesia, 2018). Lebih lanjut dinyatakan oleh Ketua KRRB Prof. Dahlanuddin bahwa pakan Lamtoro Taramba adalah tanaman perdu berasal dari Australia yang mengandung protein tinggi yang mempercepat pertumbuhan sapi dan menghasilkan daging yang berkualitas. Lamtoro juga mampu bertahan hidup di tanah kering. Pertumbuhan ternak lebih cepat, dagingnya lebih lembut, ditambah lagi oleh proses yang tepat dan penyimpanan pada suhu 2 derajat selama 14 hari. Dua faktor itu yang membedakan daging ternak yang diberi pakan lamtoro dengan daging pada umumnya. Daging sapi menjadi berkualitas, lembut dan serat daging rendah. Pertumbuhan ternak yang menggunakan pakan Lamtoro berbeda tiga kali lipat dari ternak yang menggunakan pakan seperti rumput. Sapi yang mengkonsumsi rumput maka pertumbuhannya sekitar 200 g sehari, tetapi dengan pakan lamtoro maka pertumbuhannya lebih cepat sekitar 400-600 g perhari (Diskominfo Sumbawa Barat, 2019).

Daun lamtoro mengandung nutrisi yang tinggi, menurut Putri (2012) daun lamtoro memiliki komposisi kimia yaitu bahan kering $97,89 \%$, protein kasar $23,83 \%$, serat kasar $23,5877 \%$, lemak 11,68, bahan ekstrak tanpa nitrogen (BETN) 31,0509\%, dan abu 7,73\%, sedangkan kalsium dan fosfomya berturut-turut antara 1,9-3,2\% dan 0,15-0,35\% berdasarkan bahan kering (Askar dkk ., 1997). Namun demikian pemanfaatan daun lamtoro masih terbatas, dikarenakan lamtoro mengandung zat anti nutrisi. Menurut Haryanto, 1993 dan Siregar, 1994 dalam Askar, 1997) lamtoro mengandung asam amino non protein yang disebut mimosin, yang dapat menimbulkan keracunan atau gangguan 
kesehatan apabila dikonsumsi dalam jumlah yang banyak dan terus menerus dalam jangka waktu yang cukup lama.

Lebih lanjut dinyatakan oleh Askar (1997), lamtoro mengandung zat anti nutrisi lainya yaitu asam sianida ( $\mathrm{HCN}$ ) yang berpengaruh buruk karena dapat menyebabkan terjadinya pembengkakan kelenjar tiroid pada ternak. Asam sianida dapat menyebabkan keracunan akut (mematikan) dan keracunan kronis. Pada dosis rendah HCN yang masuk dalam tubuh ternak dalam jangka waktu yang cukup lama dapat menurunkan kesehatan ternak. Siregar (1994) dalam Askar (1997) menyatakan bahwa lamtoro juga mengandung zat anti nutrisi yaitu tanin yang dapat menurunkan palatabilitas pakan dan penurunan kecernaan protein. Namun menurut Jones (1979) dan Manurung (1996) adanya sejumlah tanin dalam lamtoro dapat mencegah kembung dan melindungi degradasi protein yang berlebihan oleh mikroba rumen. Untuk mengurangi pengaruh dari zat anti nutrisi pada ternak, maka pemberian daun lamtoro sebaiknya dilayukan atau dikeringkan terlebih dahulu dan diberikan tidak secara tunggal tapi dicampur dengan hijauan lainnya seperti rumput. Pemberian kombinasi daun lamtoro dan rumput dapat membantu meningkatkan nilai gizi rumput.

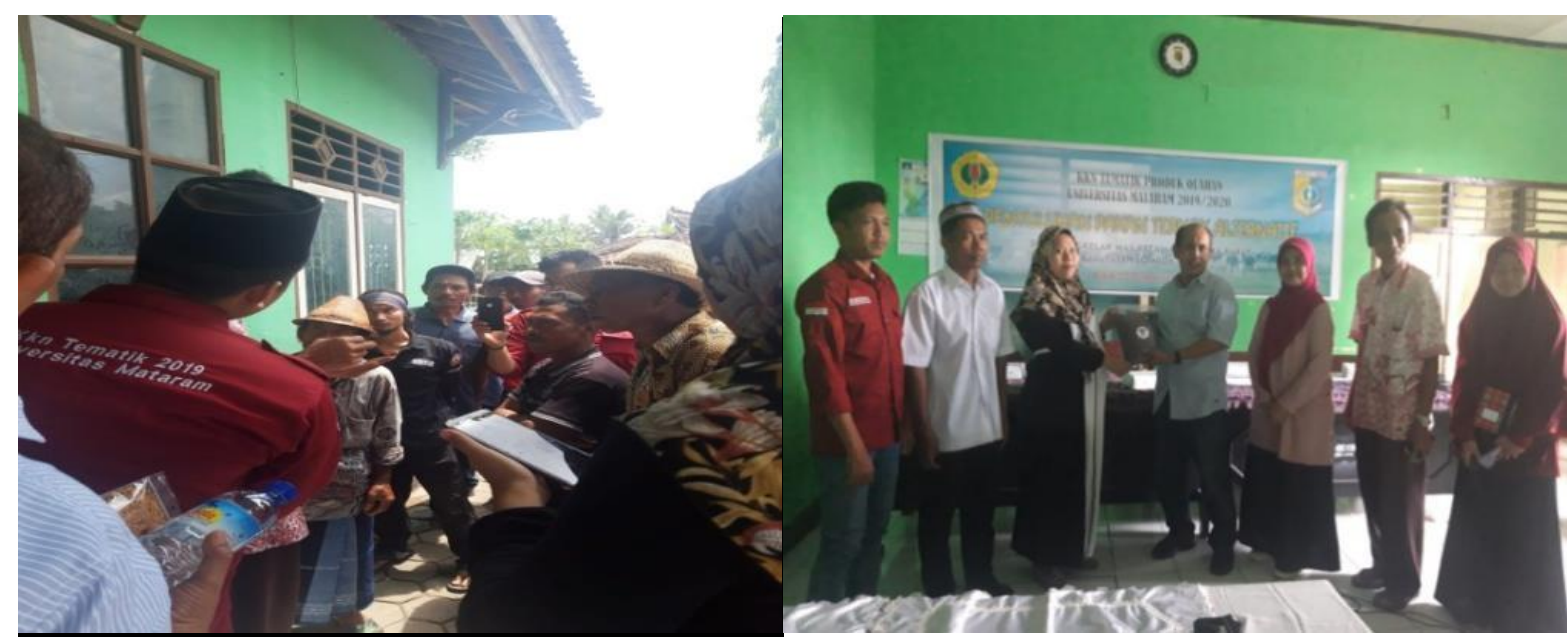

Gambar 2. Penyerahan Bibit Lamtoro dan Penyuluhan Tehnik Penanaman

Cara budidaya lamtoro taramba yang perlu diperhatikan ada 3 tahap, yaitu: pembibitan, penanaman, dan panen. Pembibitan lamtoro taramba dapat dipersiapkan dengan anakan yang dikoker (pot seeded) kurang lebih selama 2 bulan. Pada saat anakan sudah mencapai tinggi tanaman 75-100 cm, maka dipindahkan di lahan untuk dilakukan penanaman. Sistem pola penanaman dapat dalam bentuk monokultur khusus untuk kebun pakan, dalam bentuk pertanaman lorong, atau tanaman konservasi tanah dan air pada lahan berkelerengan maupun dalam larikan-larikan lebar dengan baris ganda untuk digembalakan ternak secara langsung. Tanaman lamtoro Taramba sudah siap dipanen ketika memasuki musim hujan ke dua setelah penanaman. Jika dibudidayakan untuk tujuan penggembalaan, tanaman perlu dipangkas setinggi $50 \mathrm{~cm}$ atau 1 meter setiap 4 tahun sekali untuk memudahkan bagi jangkauan ternak gembala. Pemberian lamtoro taramba ke ternak dapat diberikan sebagai pakan tunggal $100 \%$, atau dengan kombinasi $60 \%$ rumput $+40 \%$ lamtoro, atau $60 \%$ rumput $+40 \%$ lamtoro + sedikit pakan sumber energi seperti jagung, dedak padi atau umbi-umbian sebanyak 0,2\% - 0,3\% BK dari berat badan ternak (BPTP NTT, 2019). 


\section{KESIMPULAN DAN SARAN}

Kegiatan pengabdian menghasilkan peningkatan pengetahuan dan wawasan peternak dalam memanfaatkan bahan pakan alternative sebagai pakan sapi dan peningkatan semangat peternak dalam menanam biji lamtoro teramba di Desa Pengkelak Mas.

Kegiatan pengabdian selanjutnya perlu dilakukan berupa pendampingan pembuatan atau penyusunan formula pakan berbasis daun lamtoro.

\section{UCAPAN TERIMA KASIH}

Ucapan terima kasih disampaikan kepada Lembaga Pengabdian Kepada Masyarakat Universitas Mataram, Fakultas Peternakan Universitas Mataram, Kepala Desa Pengkelak Mas dan jajarannya, serta adik-adik mahasiswa KKN yang telah menjadi penghubung masyarakat desa dengan akademisi.

\section{DAFTAR PUSTAKA}

Biyatmoko, D., \& Nurlianni, A. (2012). Penambahan Niacin Pakan Berbasis serat yang Disuplementasi Minyak Ikan dan Jagung terhadap Profil Kolesterol Plasma dan Kolesterol Telur Itik Alabio. Jurnal Sain Peternakan Indonesia, 7(2).

BPTP NTT, 2019. LAMTORO TARAMBA" - Inovasi Cerdas Pengembangan Pakan Ternak di Wilayah Perbatasan RDTL-RI. http://ntt.litbang.pertanian.go.id/index.php/

Diskominfo Sumbawa Barat, 2019. Kualitas Daging Sapi Menggunakan Pakan. https://profil.diskominfo.sumbawabaratkab.go.id/

Irfan H.D., Yuwanita, T., Supadmo, \& Nurcahyanto, M. (2009). Penggunaan Limbah Udang Yang Difermentasi Dengan A. Niger Pada Pakan Broiler. JITV, 14(2), 104 - 109.

Jones, R.J . (1979). The value of Leucaena leucocephala as a feed for ruminants in tropics. World Anim . Rev ., 31, 13-23.

Manpaki, S.J., Karti, P.D.M., \& Prihatoro, I. (2017). Respon Pertumbuhan Eksplan Tanaman Lamtoro (Leucaena leucocephala cv. tarramba) terhadap Cekaman Kemasaman Media dengan Level Pemberian Aluminium Melalui Kultur Jaringan. Jurnal Sains Peternakan Indonesia, 12(1), 7181.

Manurung, T . (1996). Penggunaan hijauan leguminosa pohon sebagai sumber protein ransum sapi potong. Jumal Ilmu Ternak dan Veteriner, 1(3), 143-147.

Purnamasari, D.K., Asnawi, \& Aziz, A. (2011). Evaluasi nilai nutrisi dan logam berat ikan sapu sapu (Kajian potensi ikan sapu sapu sebagai pakan itik petelur. Jurnal Penelitian Universitas Mataram, 2(16).

Purnamasari, D.K. (2015). Tingkat Preferensi Perkutut Terhadap Pakan Yang Diberikan Pada Pemeliharaan Secara Ex situ. Jurnal IImiah Ilmu Biologi, 1(1).

Putri, D.R. (2012). Kandungan Bahan Kering, Serat Kasar dan Protein Kasar pada Daun Lamtoro (Leucaena glauca) yang difermentasi dengan Probiotik sebagai pakan ikan. Skripsi. Program Studi Budidaya Perairan, Universitas Airlangga : Surabaya.

Shahidi, F., Arachichi, J.K.V., \& Jeon, Y.J. (1999). Food Aplication of Chitin and Chitosan. Trends in Food Science and Technology, 10:37-51.

Sutama, I.N.S. (2014). Pengaruh Suplementasi Kapu Kapu (Pistonia stratiotes) dalam Ransum terhadap Kolesterol pada Serum dan daging Ayam Kampung. Laporan. Jurusan Nutrisi dan Makanan Ternak, Fakultas Peternakan, Universitas Udayana. 
Yumiaty, H., Suradi, K. 2010. Utilization of lamtoro leaf in diet on pet production and the lose of hair rabbit's pelt. Jurnal IImu Ternak, 7 (1), 73-77. 